\section{Evaluation of phytochemical contents of Emilia coccinea leaves}

\author{
Unegbu C. Chika ${ }^{2}$, Ajah Obinna ${ }^{1 *}$, Amaralam Eric Chinedu1, Anyanwu O. \\ Ogechi $^{3}$ \\ ${ }^{1}$ Department of Biochemistry, Michael Okpara University of Agriculture, Umudike, Nigeria \\ ${ }^{2}$ Department of Chemistry/Biochemistry, Federal Polytechnic Nekede, Owverri, Nigeria \\ ${ }^{3}$ Department of Pharmaceutical Technology, Federal Polytechnic Nekede, Owerri, Nigeria
}

\begin{abstract}
Emilia coccinea is widely used in folkloric medicine for eye and ear ailments as well as for fever. This present study evaluated the preliminary and quantitative

phytochemical properties of E. coccinea leaves using standard procedures. The results revealed the following bioactive compounds Flavonoids $(0.90 \pm 0.02)$, Alkaloids (0.94 \pm 0.03$)$, Tannins (10.36 \pm 0.02$)$, Saponins ( $2.34 \pm 0.02)$, Oxalate (1.62 \pm 0.01$)$, Phenols $(0.89 \pm 0.02)$, Terpenoids $(0.11 \pm 0.01)$. The high concentration of tannin and moderate concentration of other phytochemical proved that E. coccinea can serve as a vital medicinal plant that could be used for pharmaceutical formulations.
\end{abstract}

Key words:

Emilia coccinea, phytochemical, medicinal plant, metabolites

\author{
Received: \\ 03 August 2017 \\ Accepted: \\ 20 October 2017 \\ Published: \\ 27 October 2017 \\ *Corresponding Author: \\ Ajah Obinna \\ Department of \\ biochemistry, Michael \\ Okpara University of \\ Agriculture, Umudike, \\ Nigeria \\ Email: \\ ajah.obinna90@ \\ gmail.com \\ Citation: \\ Unegbu C.C., Ajah \\ Obinna, E.C. Amaralam \\ and Anyanwu, O.O. \\ (2017). Evaluation of \\ phytochemical contents of \\ Emilia coccinea leaves. \\ Journal of Medicinal \\ Botany, 1, 47-50. doi: \\ 10.25081/jmb.2017.v1.817
}

\section{Introduction}

The usage of plants in the medical systems is of great significance in almost all countries and the medicinal plants became part of many modern medicines. There are many phytochemicals and metabolites isolated from plants including steroids, terpenoids, carotenoids, flavonoids, alkaloids, tannins and cardiac glycosides (Ajibesin, 2011).

The usage of some of the secondary metaoblites from plants are not well established due to the lack of knowledge and techniques. There are many antibiotic principles in plants like anthraquinones, alkaloids etc. Now a days, the usage of medicinal plants in allopathy, herbal and many other medical systems are very common. Most of the medicinal plants are used as spices and food plants as well (Akinpelu and Onakoya, 2006). These medicinal systems are popular especially in the developing countries due to ease of obtaining and also cheaper comparing to synthetic medicine (Michael, 2002). These reasons might account for their worldwide attention and use. The medicinal properties of plants have been documented by some researchers (Michael, 2002; Akinpelu and Onakoya, 2006; Ajibesin, 2011).

Emilia coccinea, being a folkloric medicine is traditionally used as remedy for eye and ear ailments, for fever, convulsion in children, ulcer, craw-craw ringworm (Edeoga et al., 2005), rashes, measles and other forms of inflammatory diseases (Sofawara, 1996). The aim of this work is to screen for the bioactive and pharmacological potential of Emilia coccinea leaf.

\section{Materials and method Collection and identification of Emilia coccinea leaf}

Emilia coccinea was collected in the month of September, 2016 from bushes around and within FUTO, Ihiagwa in Imo State, Nigeria, during

CThis article is open access and licensed under the terms of the Creative Commons Attribution License (http://creativecommons.org/licenses/by/4.0/) which permits unrestricted, use, distribution and reproduction in any medium, or format for any purpose, even commercially provided the work is properly cited. Attribution - You must give appropriate credit, provide a link to the license, and indicate if changes were made. 
rainy season when weeds were in their maximum densities, and was identified by Botanist (Mr.) Duru C.M. of FUTO.

\section{Sample preparation and extraction}

The sample preparation and extraction of sample using maceration method were done by following the method described by Farooq (2013).

\section{Phytochemical screening of Emilia coccinea leaves \\ Mayer's test for alkaloid}

$1 \mathrm{ml}$ of Iodine and $1 \mathrm{ml}$ of potassium Iodide was used to form Mayer's reagent by mixing in a test tube. Few drops of the methanolic extract were added to the mixture in the test tube and was shaken. A reddish-brown precipitate was formed. The same procedure was repeated for the aqueous extract, and a reddish-brown precipitate also, was formed.

\section{Flavonoid test}

Few drops of the reagent $\left(\mathrm{H}_{2} \mathrm{SO}_{4}\right)$ were added to a small amount of the mathanolic extract. Immediate development of orange color indicated the presence of flavonoid in the methanolic extract. The same was done for the aqueous extract and an orange color was also gotten.

\section{Saponin test}

About $0.5 \mathrm{ml}$ of the extract was shaken with $5 \mathrm{ml}$ of distilled water.

\section{Test for steroid}

$5 \mathrm{ml}$ of the extract (Methanolic) was added with $2 \mathrm{ml}$ of acetic anhydride, each with $2 \mathrm{ml}$ of $\mathrm{H}_{2} \mathrm{SO}_{4}$. The color was changed from violet to green. Same was done and gotten for the aqueous extract.

\section{Test for terpenoid}

$5 \mathrm{ml}$ of the extract (Methanolic) was mixed with $2 \mathrm{ml}$ of chloroform and $3 \mathrm{ml}$ concentrated $\mathrm{H}_{2} \mathrm{SO}_{4}$. A layer was formed, and a reddish-brown color appeared in the inner face, indicating the presence of terpenoid. Same was done and gotten for the aqueous extract.

\section{Test for tannins (ferric chloride test)}

$0.5 \mathrm{ml}$ of each extract was dissolved in $10 \mathrm{ml}$ of distilled water, and then filtered.
Two drops of Ferric chloride solution were added to the filtrates, and a blue-black precipitate was formed, indicating the presence of tannins.

\section{Test for phenol}

$0.5 \mathrm{~g}$ of the extracts (Methanolic and aqueous) were dissolved in $5 \mathrm{ml}$ of distilled water. Few drops of neutral 5\% ferric chloride solution were added. A dark green color was formed, indicating the presence of phenolic compounds.

\section{Quantitative test \\ Flavonoid determination}

$2 \mathrm{~g}$ of sample was weighed into a beaker. $100 \mathrm{ml}$ of $2 \mathrm{M} \mathrm{HCl}$ solution was added and was boiled for 30 minutes. It was then cooled and filtered. Titrate was treated with drop wise solution of $5 \mathrm{ml}$ ethyl acetate. Ethyl acetate layer containing flavonoid was collected and the aqueous layer was discarded. A pre-weighed filter paper was used to filter the ethyl acetate extract, which was then dried in an oven at $100^{\circ} \mathrm{C}$ for 30 minutes. It was cooled in the dessicator, and was re-weighed, and calculated using the formula

$$
\% \text { flavonoid }=\frac{W 2-W 1}{W t \text { of sample }} \times \frac{100}{1}
$$

\section{Alkaloids determination}

$2 \mathrm{~g}$ of the sample was weighed. It was then soaked in $20 \mathrm{mls}$ of $10 \%$ Ethanolic acetic acid. It was allowed to stand for 4 hours at room temperature. The concentrated filtrate was filtered. It was then extracted by evaporation over a steam bath to $1 / 4$ its original volume. Concentrated ammonia hydroxide was added in drops until in excess to extract alkaloid precipitate. Alkaloid precipitate was recovered by filtration, through a pre-weighed filter paper. The alkaloid precipitate was then washed with1\% ammonia solution and was dried in the oven at $60^{\circ} \mathrm{C}$ for 30 minutes. It was cooled in a dessicator and was re-weighed. The $\%$ Alkaloid was calculated using the formula;

$$
\% \text { Alkaloids }=\frac{W 2-W 1}{\text { Weight of sample }} \times \frac{100}{1}
$$

\section{Saponin determination}

$2 \mathrm{~g}$ of the sample was weighed. $50 \mathrm{mls}$ of $20 \%$ aqueous ethanol solution was added. The solution was heated with periodic agitation for $90 \mathrm{~min} 55^{\circ} \mathrm{C}$ in a water bath. It was then filtered, and the residue was extracted with $50 \mathrm{mls}$ of $20 \%$ ethanol. Both extracts were re-pooled together and the combined extract was reduced to $40 \mathrm{mls}$ 
at $90^{\circ} \mathrm{C}$. It was then transferred to a separating funnel and 40mls of diethyl was added and it was shaken vigorously. It was then separated by partition. Re-extraction by partition was done repeatedly until the aqueous layer was cleared. Saponin was then extracted with $60 \mathrm{ml}$ of $\mathrm{N}$ butanol. Extracts were washed with $10 \mathrm{ml} \mathrm{5 \%}$ aqueous $\mathrm{NaCl}$ solution. It was evaporated to dryness in a pre-weighed evaporating dish after retaining upper part. It was then dried in the oven at $60^{\circ} \mathrm{C}$, and was re-weighed. $\%$ saponin was calculated thus;

$$
\% \text { saponin }=\frac{W 2-W 1}{\text { Weight of sample }} \times \frac{100}{1}
$$

\section{Tannin determination}

$1 \mathrm{~g}$ of the sample was weighed into a beaker. $25 \mathrm{ml}$ of distilled water was added. It was shaken and was allowed to stand for 30minutes, but with 10 minutes interval shake. It was then filtered into a clean beaker. $5 \mathrm{ml}$ of the filtrate was taken, and $1 \mathrm{ml}$ of $\mathrm{FeCl}_{3}$ and potassium farrocyanide was added. It was made up to $50 \mathrm{ml}$ with distilled water. Absorbance was read at a wave length of $760 \mathrm{~nm}$, and $\%$ tannin was calculated thus;

$$
\% \text { Tannin }=\frac{100}{w} \times \frac{A u}{A s} \times \frac{C}{1000} \times \frac{V f}{V a} \times \mathrm{D}
$$

\section{Phenol determination}

0.2 of sample was dispensed into a test tube. $10 \mathrm{ml}$ of methanol was added, and it was shaken thoroughly. The mixture was allowed to stand for 5 minutes and was filtered. $1 \mathrm{ml}$ of the filtrate was measured out into a test tube. $1 \mathrm{ml}$ of follins reagent, and $5 \mathrm{ml}$ distilled water was added. The color was allowed to develop for about 3 to 4 hours at room temperature. The absorbance was then taken at $760 \mathrm{~nm}$, and $\%$ phenol was calculated thus;

$$
\% \text { phenol }=\frac{100}{w} \times \frac{A u}{A s} \times \frac{C}{1000} \times \frac{V f}{V a} \times \mathrm{D}
$$

\section{Oxalates determination}

$2 \mathrm{~g}$ of sample flour was suspended in $190 \mathrm{ml}$ of $\mathrm{H}_{2} \mathrm{O}$ in a $250 \mathrm{ml}$ volumetric flask. $10 \mathrm{ml}$ of $6 \mathrm{M}$ HCL was then added The mixture was heated at $100^{\circ} \mathrm{C}$ for 1 hour. It was cooled and was made up to $250 \mathrm{ml}$, and was after which Filtered. Duplicate portion of $125 \mathrm{ml}$ of the filtrate were measured into beakers. 4 drops of methyl red indicator was added. Conc. $\mathrm{NH}_{4} \mathrm{OH}$ was added in drops until test solution changed from pink color to a faint yellow. Each portion was heated to $90^{\circ} \mathrm{C}$. They were cooled and then, filtered. The filtrate was heated at $90^{\circ} \mathrm{C}$ and $10 \mathrm{ml}$ of $5 \% \mathrm{CaCl}_{2}$ was added and was constantly stirred. It was cooled and was left over night at $50^{\circ} \mathrm{C}$. It was then centrifuged at $25000 \mathrm{rpm}$ for 5 minutes. The supernatant was decanted and was dissolved in $100 \mathrm{ml}$ of $20 \%$ $\mathrm{H}_{2} \mathrm{SO}_{4}$. The filtrate resulting from digestion of $2 \mathrm{~g}$ of flour was made up to $300 \mathrm{ml}$. Aliquot of $125 \mathrm{ml}$ was heated until near boiling. It was then titrated against $0.05 \mathrm{M} \mathrm{KMnO}_{4}$ solution to a faint pink color which persisted for 30secs, and was calculated using the formular;

\section{Terpenoid test}

$$
\frac{T x(\text { Vme })(D f) \times}{(\text { ME }) \times M f} 105(\mathrm{mg} / 100 \mathrm{~g})
$$

$2 \mathrm{~g}$ of the plant leaf powder was weighed and soaked in $50 \mathrm{ml}$ of $95 \%$ ethanol for 24 hours. The extract was then filtered, and the filtrate was extracted with petroleum ether at $60^{\circ} \mathrm{C} /$ It was then concentrated to dryness, and the dried ether extract was treated as total terpenoids. Thus;

$$
\% \text { Terpenoid }=\frac{W 2-W 1}{\text { Weight of sample }} \times \frac{100}{1}
$$

\section{Result and discussion}

The results of the phytochemical screening of the extracts revealed that flavonoids, alkaloids, terpenoids, saponins, steroid, steroid, phenol. Terpenoids, were present in the extracts from methanol and water as shown in table 1 below.

Table 1. Qualitative phytochemical constituent of the extracts.

\begin{tabular}{lll}
\hline \multirow{2}{*}{ Constituents } & Extracts & \\
\cline { 2 - 3 } & Aqueous & Methanol \\
\hline Flavonoids & + & + \\
Alkaloids & + & + \\
Tannins & ++ & + \\
Saponins & + & - \\
Steroids & + & + \\
Phenols & + & + \\
Terpenoids & + & + \\
\hline +: Indicate presence of phytochemicals. & &
\end{tabular}

Table 2. Quantitative determination of phytochemical constituents of E. coccinea leaf.

\begin{tabular}{lll}
\hline Sample & Constituents & Value $(\mathrm{Mg} / 100 \mathrm{~g})$ \\
\hline & Flavonoids & $0.90 \pm 0.02$ \\
& Alkaloids & $0.94 \pm 0.03$ \\
& Tanninss & $10.36 \pm 0.02$ \\
Saponins & $2.34 \pm 0.02$ \\
Oxalate & $1.62 \pm 0.01$ \\
Phenol & $0.89 \pm 0.02$ \\
& Terpenoids & $0.11 \pm 0.01$ \\
\hline Values are mean \pm standard deviation of triplicate determination.
\end{tabular}


The present study carried out on Emilia coccinea revealed the presence of medicinal active constituents. The phytochemical compounds of Emilia coccinea analyzed are presented in Table 1 and 2 above.

From this study, the preliminary phytochemical content of E. coccinea leaf reviewed the presence of alkaloids, flavonoids, tannins, saponnins, phenols, cardiac glycoside, terpenoids, steriods. The quantitative phytochemical contents were found to be, Flavonoid $0.90 \pm 1.64 \mathrm{mg} / 100 \mathrm{~g}$, Alkaloid $0.94 \pm$ $1.77 \mathrm{mg} / 100 \mathrm{~g}$, Tannins was relatively high in the E. coccinea leaf, with $10.36 \pm 214.45 \mathrm{mg} / 100 \mathrm{~g}$, Sapnninss $2.34 \pm 10.99 \mathrm{mg} / 100 \mathrm{~g}$, Cardiac glycoside $0.27 \pm 0.15 \mathrm{mg} / 100 \mathrm{~g}$, oxalate $1.62 \pm$ $5.25 \mathrm{mg} / 100 \mathrm{~g}$, Phenol $0.89 \pm 1.57 \mathrm{mg} / 100$, and Terpenoids $0.11 \pm 0.02 \mathrm{mg} / 100$.

There is significant action of phytochemicals in treating various diseases (Kilani, 2006; Kilonde et al., 2004). Steroids, are important part of modern medicine as their relationship with such compounds as sex hormones (Benjamin, 2005). Steroids compounds are good for breast feeding and expectant mothers, as they could serve as potent starting material in synthesis of hormones (Benjamin, 2005).

Phenolic and flavonoids are major phytochemicals with significant role in medicine (Azaizeh et al., 2003). They have many significant actions likes antiapoptosis, anti-aging, anticarcinogenesis, etc. (Falodun et al., 2006; ElMahmood et al., 2010).

\section{Conclusion}

The extract of E. coccinea leaf showed significant phytochemical constituents, which supports the traditional use of this plant in various diseases and/or ailments amelioration.

\section{References}

Ajibesin K.K. (2011). Dacryodes Edulis (G. Don) H.J. Lans: A review on its medicinal, phytochemical and economical properties. Research Journal of Medicinal Plant, 5 (1):32-41

Akinpelu, D.A. and Onakoya, Z.T.M. (2006). Antinicrobial activities of medicinal plants used in folklore remedies in South-Western Nigeria. African Journal of Biotechnology 7 (5):1078-1081.

Azaizeh, H., Fulder, S., Khalil, K. and Said, O. (2003). Ethnomedicinal knowledge of local
Arab practitioners in the Middle East region. Fitoterapia, 74: 98-108

Benjamin, L. H. (2005). The Evolution of Herbal Medicine. "BehaviouralPerspectives", 70 (2): 1

Edeoga, H.O., Okwu, D.E., and Mbaebie, B.O. (2005). Phytochemical constituents of some Nigeria medicinal plants. African Journal of Biotechnology, 4 (7):685-688.

El-Mahmood, A.M., Doughan, J.H. and Kiaman, H.S. (2010). In Vitro antimicrobial activity of crude leaf and stem bark extracts of Gmelina arborea (Roxb) against some pathogenic species ofEnterobacteriaceae. African Journal of Pharmacy and Pharmacology, 4(6): 355-361.

Falodun, A., Okunrobo, L. O. and Uzoamaka, N. (2006). Phytochemical screening and antiinflammatory evaluations of methanolic and aqueous extracts of Emphobia beterophylla Linn (Emphobiaceae). African Journal of Biotechnology, 5 (6): 529-531.

Farooq, T. (2013). Phytochemical and Pharmacological Investigation of the Leaves of Carica papaya Linn (Doctoral dissertation, East West University).

Kilonde, C.H., Fidahusein, D.S., Lukhoba, C.W. and Jumba, M.M. (2004). Antimicrobial activity and phytochemical screening of Senna didymobotry used to treat bacterial and fungal infections Kenya, International Journal of Education and Research, 2 (1): 1-12.

Kilani, A. M. (2006). Antibacterial assessment of whole stem bark of "Vitex doniana" against some enterobacteriaceae. "African Journal of Biotechnology", 5 (10): 958-959.

Michael, A. (2002). Trees, shrubs and lianas of West African dry zones, Mangraf Publishers GMBH Pans, pp. 506-511.

Sofawara, E. A. (1996). Research on medicinal plants and traditional medicine in Africa. Journal of Alternative and Complementary Medicine”, 2 (3): 365-372. 